\title{
Izborni zakon Bosne i Hercegovine i limiti etnonacionalne paradigme
}

\author{
Pavle Mijović \\ Izvanredni profesor Katoličkog bogoslovnog fakulteta \\ Univerziteta u Sarajevu \\ pavlemc@gmail.com
}

Sažetak: Izborni zakon Bosne i Hercegovine predstavlja, u svojoj specifičnoj pravnoj formi, vjeran odraz općih načela definiranih Daytonskim ustavom koja su i kalcificirala etničku podjelu zemlje. Interdisciplinarni pristup konstitucionalnim odrednicama prisutnim i u izbornom zakonu pokazuje jasne crte političke svijesti koja ga je donijela.

Prvi dio članka pokušava rekonstruirati dominantnu političko-društvenu ideju u pozadini izbornog zakona. Izborni zakon Bosne i Hercegovine ogledni je primjer nedovršene konstitucionalne i državne arhitekture, posebice u vidu nedovršenog etnonacionalnog fiksizma te problematike ljudskih prava. Etnonacionalna paradigma, evidentna još od prvih višestranačkih izbora u Bosni i Hercegovini, više od samog izbornog procesa ukazuje na etničko svrstavanja. Stoga će koncept „statističke nacionalizacije“ biti analiziran.

Drugi dio članka konfrontira dominantnu ideju izbornog zakona Bosne i Hercegovine s određenim aspektima političke teorije. Ustavna kategorija konstituenata je privilegirana u odnosu na kategoriju „Ostalih“, što predstavlja eklatantan primjer diskriminatorne prakse, koji očekivano, nije u skladu s bilo kojim normativnim dokumentom vezanim za ljudska prava. Čak i iz etnonacionalne perspektive, navedeni Izborni zakon je nedovršen. Nadalje, inherentni limiti konsocijacijskog okvira su analizirani.

Treći dio članka analizira ograničenja etno-partitokracija pokazujući kako je u jednom takvom sistemu, individualna perspektiva gotovo nepostojeća. Obrisi kritičke teorije ukazuju na nužnost alteracije određenih društvenih stvarnosti te stvaranja društvenog modele osjetljivog na različitosti ali usmjerenog prema razvijenim demokratskim tekovinama.

Ključne riječi: izborni zakon $\mathrm{BiH}$, etnonacionalna paradigma, statistička nacionalizacija, konstituenti, inkluzija

\section{Uvod}

Izborni zakoni su u velikoj većini država shvaćeni s negativnim predznakom. Svojevrsna odioznost koja često prati gotovo svaki zakon, poprilično je vidljiva na primjeru izbornih zakona. Naime, izbori, koji su sami po sebi masivan fenomen, generiraju, uz relativne pobjednike/pobjednika također i one druge, gubitnike izbora. Kombinatorika postizbornog koaliranja koja je 
većinom po funkcionalnom ili interesnom ključu stvara dodatnu diskrepanciju između elektorata i stranačke mašinerije.

Izborni zakon Bosne i Hercegovine rekurentna je politička tema, koja se odvija na Putnamovoj matrici, kao igra na dvije razine. Iz unutarnje perspektive Bosne i Hercegovine, jedna od etnonacionalnih stranaka, Hrvatska demokratska zajednica, insistira na promjeni istoga kako bi se udovoljilo presumptnoj jednakopravnosti i kako bi, kvantitativno gledano najmalobrojniji narod mogao birati svoje, ističe se, „legitimne predstavnike”. Budući da unutar svakog federativnog okvira uvijek postoji mogućnost, popularnog preglasavanja, predlaže se varijacija na temu teritorijalne izborne jedinice koja bi imala za cilj, ističe se, osiguravanja potpune jednakopravnosti. Navedeni stav je sasvim koherentan s generalnim standardnima stranaka s etnonacionalnim predznakom, koje se i programski i deklarativno određuju kao protektori svog nacionalnog bića, čiju volju, smatra se, ekskluzivno predstavljaju te kao takva ista mora biti transponirana na sve političke razine predstavljanja.

Iako su svi politički stavovi sasvim razumljivi i legitimni, druga razina igre, ona višeg reda, vezana za Izborni zakon $\mathrm{BiH}$, ona iz perspektive međunarodnih uzusa vezanih za ljudska prava, isti naziva duboko diskriminatornim prema kategoriji “Ostalih”, kojima je uskraćena mogućnost kandidiranja za mjesto člana predsjedništva i mjesto u Domu naroda. Iako niti razvijene zemlje nisu lišene diskriminatornih elemenata u izbornim zakonima, poput rasne, etničke, klasne, korporative, spolne preferencija, diskriminacija koja je konstitucionalno prisutna u izbornom zakonu $\mathrm{BiH}$ je nažalost, eklatantnog tipa. Konkretnim pojedincima koji nisu pripadnici konstitutivnih naroda oduzeta je mogućnost kandidiranja za gore spomenute javne funkcije. Bosna i Hercegovina i nakon više od dekade nije u mogućnosti izvršiti navedenu presudu.

Rad analizira etnonacionalnu paradigmu, koja se, na nedovršen način, kodificirala u Izbornom zakonu, te koja posjeduje inherentne limite, posebice u vidu poštivanja ljudskih prava, vezanih za izbornu utrku, kategorije “Ostalih". U zadnjem dijelu rada predlaže se, na Habermasovom tragu, razvijanje zajedničkog političkog jezika, koji nadilazi sve tri političke ento-subkulture. 


\section{Normiranje entonacionalne paradigme unutar izbornog zakona}

\section{Problem političkog pluralizma i etnonacionalni boom}

Prvim postdaytonovski izbori su, insajderskim i direktnim rječnikom Richarda Holbrooke „ojačali separatiste koji su i započeli rat” (Usp. Holbrooke, 2011, 180-181). Iako je navedeno, i sam će Holbrooke istaći, mnogima poslužilo kao dokaz o općoj želji podjele zemlje po etničkim linijama, njemu osobno i nije. On je to shvatio kao dokaz da je opća atmosfera bila dominirana istim ljudima koji su i započeli rat, a zagovornici pomirenja su u svim zajednicama bili relativno marginalizirani. Belloni također ističe kako su prvi postratni izbori naprosto konsolidirali etnički ekskluzivizam, te su se pretvorili naprosto u etnički cenzus (Usp. Belloni, 2004, 337).

Ova Holbrookovim riječima sveprisutna „opća atmosfera“ uzdignuta je, posebno za vrijeme mirovnih pregovora koji su prethodili nastanku Ustava, na pijedestal normativnog, te se kodificirala u samom ustavu Bosne i Hercegovine i utjecala na daljnju izgradnju svih društvenih struktura. Separatizam, fragmentacija, parcelizacije, sastavnica gotovo svakog političkog života, u bosanskohercegovačkom slučaju, pokazuju dodatne polarizirajuće tendencije. Ustavni okvir Bosne i Hercegovine, posjeduje naglašene centrifugalne tendencije ${ }^{1}$ te generalno umanjuje mogućnosti društvene kohezije.

Sam izborni zakon je koncipiran kao integralni dio Daytonskog mirovnog sporazuma kojim je u jesen 1995. okončan rat te stvorena nova državna infrastruktura. S ciljem okončanja rata, smatramo kako je svaki mirovni sporazum hvale vrijedan. No, također, držimo kako svaka ustavna arhitektura ne smije predstavljati konvencionalni fiksizam, čiji se inherentni limiti reflektiraju na opću društvenu sliku (Usp. Weller-Wolf, 2005, 43-49). Izborni zakon Bosne i Hercegovine ogledni je primjer nedovršene konstitucionalne i državne arhitekture, posebice u vidu etnonacionalnog fiksizma te problematike ljudskih prava, o kojima će biti riječ u nastavku.

Iako Daytonski ustav posjeduje svoju specifičnu problematiku, ipak se čini kako je navedena problematika prisutna u javnoj sferi još od prvih višestranačkih izbora. Etnonacionalna paradigma dominira javnom sferom još od prvih višestranačkih izbora u Bosni i Hercegovini. Razdoblje koje joj je prethodilo, jednostranački politički sustav koji se u 20. stoljeću manifestirao većinom u tri forme, isprva u formi fašizma, zatim komunizma a kasnije i

\footnotetext{
${ }^{1} \mathrm{O}$ razlici centrifugalnih i centripetalnih tendencija u političkim strankama konzultirati: Sartori, Giovanni. Parties and party systems: A framework for analysis. ECPR press, 2005, 128.
} 
zemalja u razvoju, među kojima su bile i bivše kolonije, početkom devedesetih godina gotovo da je predestiniran na disoluciju. Ako perspektivu suzimo samo na unutar prostora bivše Jugoslavije, već tijekom 20. stoljeću, izborna povijest je generalno podijeljena na dva različita razdoblje. Prva obuhvaća višestranačje unutar Prve Jugoslavije, unutar kojega su mnoge stranke reprezentirale etničke zajednice dok druga obuhvaća jednostranačje za vrijeme Druge Jugoslavije (Usp. Rabushka- Shepsle, 1972, 186-199). Stranački, nazovimo ga etno-okvir, nije stoga novi fenomen, već je u određenoj mjeri i prethodno prožimao određene društvene strukture, što je i sasvim očekivano.

Promjena paradigme i tranzicija s jednostranačje na višestranačje zahtijevalo je inoviranje ustavne arhitekture, isprva u formi amandmana na postojeće ustave, što je bio slučaj u Bosni i Hercegovini, koji je ustavno omogućio prve višestranačke izbore. Višestranačje je, poznato je, najkarakterističniji oblik organiziranja političkih stranaka, izuzmemo li dvostranačje, koje egzistira većinom u visoko razvijenim demokracijama anglosaksonskog tipa. Višestranačje predstavlja, doduše ne bez specifičnih problema i izazova, jedan od vrhunaca moderne predstavničke demokracije. Perspektiva postaje pluralna, što zasigurno predstavlja jedan nužan demokratski skok, ali navedeno dovodi do specifičnih izazova. Razdoblje koje je prethodilo prvim višestranačkim izborima u Bosni i Hercegovini, dobar dio jedne dekade, okarakteriziran je kao doba permanentne socio-političke krize na prostoru bivše Jugoslavije.

S početkom višestranačja (Usp. Bieber, 2014, 548-555) nova politička paradigma koja je imala razviti se kao bazu vlastitog djelovanja uzima ideju etniciteta. Etnicitet, koji isključivo promatramo operacionalizirajući potencijal političkog grupiranja i djelovanja, već krajem 80-ih godina prošlog stoljeća uzima primat gotovo svim drugim motivima političkog djelovanja. Time on postaje novi standard političkog udruživanja. Etnicitet predstavlja jedan poprilično ambivalentan pojam, u smislu da njegove konotacija i implikacije predstavljaju primordijalne konture, predmoderne, političkog djelovanja a nikako jasno razrađene programske smjernice. No, ne čudi što se u pluralnim društvima ponovo javljaju slični fenomeni. U slučaju bivše Jugoslavije, radilo se o „etničkom regionalizmu“, dok primjerice određene zemlje većinom Trećeg svijeta, poput Konga, Sudana, Nigerije, karakterizira tribalizam (Usp. Rabushka- Shepsle, 1972).

Generalna aklamacija i prihvaćanje etniciteta kao temelja političkog djelovanja možda ukazuje i na činjenicu kako kroz duže razdoblje permanentne krize, ljudska aktivnost se usmjerava na primordijalne mehanizme i datosti, poput onih etničkih. Svekoliki kontekstualni razlozi su zasigurno pogodovali nastanku istih. 
Malešević dobro primjećuje kako je dominantni izborni sentiment na prvim višestranačkim izborima bio vezan za svojevrsno ,predgrađansko i predpolitičko stanje“ (Malešević, 1991, 318) koje se poglavito očitovalo u „minornom ili gotovo nikakvom utjecaju programa i kandidata na političko opredjeljenje birača. Iako je, očekivano, bilo nemoguće razviti konture „retrospektivne teorije glasanje, u kojoj elektorat na temelju prethodnog iskustava s izabranima honorira isto ili ne, u Bosni i Hercegovini je nastupila retrospektivna teorija glasanja, u izvornom jezičnom smislu. Pogledi elektorata su bili usmjereni daleko u prošlost, Maleševićevim riječima „Nacionalnoreligijski faktori su imali apsolutni prioritet“" (Malešević, 1991, 315). On dobro opisuje kontekst:

„Nacionalna prebrojavanja, podjele, svrstavanja i homogenizacije su u ovim izborima snažno manifestovane. Sve vrste kriza, strahovanja i neizvjesnosti transponovane su u fetišizam nacionalnog fenomena, kao posljednjeg i jedinog »sigurnog zaštitnika« pred ponorom neizvjesnosti. Neizvjesna budućnost Be Ha i Jugoslavije u očima velikog broja građana je tu bila od primarnog značaja. To je istovremeno predstavljalo povoljnu okolnost za uspješnu manipulaciju nacionalnim i vjerskim osjećajima ljudi, za pothranjivanje novih kolektivističkih iluzija, do optuživanja čitavih naroda, širenja predrasuda, pa i mržnje prema njima. Rezultat toga je širenje straha među ljudima i osjećaja lične, građanske, političke, socijalne, egzistencijalne i nacionalne nesigurnosti. Nema sumnje da je njihovo političko opredjeljivanje bilo pod tim pritiskom. Neke stranke su to uspješno instrumentalizirale“. (Malešević, 1991, 324).

\section{Statistička nacionalizacija}

Izborni rezultati to jasno pokazuju. Mirko Pejanović precizno primjećuje kako su prvi višestranački izbori pokazali više od pluralizacije i stranačkog opredjeljivanja - etničko svrstavanje (Usp. Pejanović, 2016). Ili, preciznije, tri nacionalne stranke, predstavljene kao reprezentanti nacionalnih interesa, osvajaju $84 \%$ poslaničkih mandata u republičkoj skupštini. Ostalih šest stranaka, ukazuje Malešević na njihov skroman rezultat, uzimaju jedva 14\% poslaničkih mjesta te samo zahvaljujući proporcionalnom izbornom modelu kod izbora poslanika u Vijeće građana ovih osam stranaka ulazi u Parlament. Tako se i ovdje pokazala stanovita prednost proporcionalnog nad većinskim, pogotovu apsolutno većinskim izbornim principom, ističe Malešević (Malešević, 1991, 323). 
Etnicitet ovdje shvaćamo kao političko operalizirajući potencijal, a ne kao singularno iskustvo življenja, kojega i sam etnicitet zasigurno determinira, manje ili više, ovisno o samom pojedincu. Na primjeru općeg popisa stanovništva, i naš metodološki odabir postaje jasniji. Kvantifikacija stanovništva predstavlja oblik socijalne ontologije. Naš pristup ukazuje kako je primjerice opći censuz stanovništa, koji je pokazao ili konstatirao etničku pripadnost, imao dvostruku funkciju, koje su se kasnije operacionalizirale i politički. Prva je bila katalogizirati etnički sam teritorij Bosne i Hercegovine, a druga, kvantificirajući sam teritorij, odrediti buduće interesne sfere raznih politički aktera. Naime, opći popis stanovništva (u ovom slučaju referentan je bio onaj iz 1980.) koji u svim izbornim ciklusima služi kao svojevrsna referentna točka, kvantitativno je pokazao zastupljenost pojedinih nacija i taj, izmjereni element poslužio je kao osnova za daljnji izborni inženjering. Kolokvijalno nazvano „stanje na terenu“ poslužilo je kao temeljni element za buduće političko planiranje. Navedeno nije predstavljalo isključivo bosanskohercegovački specificum. Primjerice, opći popis stanovništva Libanona iz 1933., i fiksirani „omjer snaga“ koji iz toga proizlazi je i danas referentna točka za famozni ,power-sharing“ $u$ toj zemlji, koju generalno krasi visok stupanj političke nestabilnosti.

U shvaćanju koncepta „statističke nacionalizacije“ i budućih političkih implikacije, može nam pomoći analiza Rogersa Brubakera koji smatra kako je od velike važnosti ,jaki institucionalizirani etnonacionalno klasifikatoran sistem koji određene kategorije čini spremnima i legitimnima za reprezentaciju društvene stvarnosti, političkih ciljeva i organizacije političkog djelovanja“" (Brubaker, 2004, 54).

No, klasifikacija stanovništva je postojala, očekivano, i u nešto daljoj prošlosti i to ne samo na prostoru bivše Jugoslavije. Proces etničke atribucije ili svrstavanja, kako ga Gerald Stourzh naziva, vidljiv iz popisa stanovništva, imao je za cilj, kolektivizirati individualne identitete (Usp. Stourzh, 2010, 154). Iako Stourzh analizira period od sredine 19. stoljeća, dakle poprilično davno, njegove ideje o etničkoj atribuciji koja je imala za cilj pacificirati divergentne konstituente multinacionalnog carstva, poput onog Austro-Ugarskog, imala je „dobre namjere ali loše posljedice“ kako će Stourzh reći, referirajući se na navedeni period te turbulencije koje su iz toga proizašle. Rok Stergar i Tamara Scheer će analizirajući period navedenog multinacionalnog carstva i slijedeći Stourzhove ideje, istaknuti kako je neželjena posljedica birokratske klasifikacije, koja se primjerice ogledavala u klasifikaciji jezika, dovela do shvaćanja pojedinaca pa i čitavih kolektiva kao "etničkih kutija", koje će 
kasnije biti lagano politički usmjerene i po potrebi, instrumentalizirane (Usp. Stergar-Scheer, 2018, 575-591).

Prvi višestranački izbori u Bosni i Hercegovini nisu mogli nego reprezentirali tu predmodernu socijalnu ontologiju na politički plan. U javnu sferu hektično ulaze koncepti, ideje, stavovi, koje je gotovo nemoguće učiniti kompatibilnima sa modernim pluralnim društvenim dinamikama. Programska načela etno-nacionalnih stranaka, koja gotovo da i nisu uopće postojala $u$ modernom smislu, kodificirana su te su se većinom temeljila na retrogradnim koncepcijama gotovo svih konstituenata moderne države, počevši od ekskluzivne koncepcije (vlastitog) naroda, reduktivne vizije teritorija, do inherentno dezintegrativnih dinamika. Proces demokratizacije društva, počevši od prvih višestranačkih izbora, vodio se dijametralno suprotnim dinamikama u odnosu na društvene-političke tokove u Europi, u kojima se potencirao integracijski potencijal iste. No, demokratizacija je iznimno kompleksan proces, koji u svojim fundativnim fazama, kakva je bila i početak višestranačja, slijedi određene rudimentarne dinamike. Dok su navedene donekle i očekivane kada se radi o početnim trenutcima demokratizacije, iste postaju potpuno neshvatljive kada su shvaćene kao fiksan cilj svakog društvenog okvira.

\section{Limiti konsocijacije, konstituenti i ekskluzija „Ostalih“6}

\section{Konstituenti i ekskluzija ,Ostalih“}

Razvoj političkog procesa u pluralnim društvima, koje karakterizira politička organiziranost koja slijedi etničke linije, odvija se u nekoliko faza, tvrdi Rabushka. Prva faza je ona prije nezavisnosti (govori se većinom o zemljama postkolonijalnog nasljeđa ili država federativnog ustrojstva) u kojoj se različiti etnički potencijal grupira i mobilizira kako bi zajednički srušili vladajući režim. Navedeno je bilo očito na prvim višestranačkim izborima. No, erozija je brzo nastupila. Pokazati će se kasnije u bh slučaju kako „ortačke koalicije“, slijedeći Rabushkin teoretski model, počinju erodirati čim u pitanju dođe raspodjela političkih ili inih drugih resursa (Usp. Rabushka, 2009, 219). Rat je, očekivano, dodatno nagrizao bilo kakvu mogućnost inoviranja političke arhitekture.

Nakon rata u Bosni i Hercegovini okončanim mirovnim ugovorom, privilegirane su tri glavne etničke grupe - Bošnjaci, Hrvati i Srbi, koji su označeni kao „konstitutivni“ narodi. Nije sporno kako navedene sastavnice predstavljaju, kvantitativno, najveći dio same populacije. No, čini se kako je društvena 
cjelina reducirana na svoje elementarne komponente koje su etničkog karaktera, i koje dobivaju novi naziv - konstituenti.

Sam termin konstituent je poprilično ambivalentnog značenja, iako ćemo ga ovdje promatrati, s Andrewom Rehfeldom, u kontekstu političkog predstavljanja, koji legitimira samu demokraciju i uvjetuje institucionalni dizajn. I sama etimologija je poprilično ekstenzivna, a i korištenje termina je variralo kroz stoljeća. Na početku 18. stoljeća riječ konstituent je bila vezana za samo glasanja, dok kasnije postaje shvaćena kao dio neke veće širine. Ponekad je shvaćena individualno, ponekad ima kolektivne konotacije (Usp. Rehfeld, 2005, 34). Ako konstitutivnost shvatimo kao "način na koji država definira grupe građana s ciljem izbora političkih predstavnika" (Usp. Rehfeld, 2005, 36), onda je lagano zaključiti s Rehfeldom kako su konstituenti u Bosni i Hercegovini definirane na religijskoj ili etničkoj matrici (Usp. Rehfeld, 2005, 36-38). Radi se o predmodernom okviru koncepcije političke stvarnosti. U kontekstu razvijenijih demokracija, dobrano evoluiranim i modernim, navedene teme su potpuno opsoletnog karaktera.

No, u bosanskohercegovačkom slučaju je drugačije. Ono što odudara od konstitutivne matrice, dakle društveni ostatak, etiketiran je vrlo pejorativnim terminom „ostali“. Riječ je pojedincima, primjerice autohtonim nacionalnih manjina, među kojima su i ona židovska i romska ali i pojedincima koji se ne deklariraju kao jedan od konstitutivnih naroda. Iako građani u punom smislu, ustav ih etiketira kao „Ostali“ i uskraćuje im pravo da se kandidiraju za člana predsjedništva i Dom naroda. Iako su slične diskriminirajuće tendenciju su prisutne u raznim oblicima u 20. stoljeću, izgleda da je BiH jedina zemlja na svijetu sa ustavom koji neke svoje građane konstitucionalno kategorizira kao "Ostale".

Iako elementi diskriminatorne prakse prisutni su, doduše u mnogo manjoj mjeri (Usp. Holden, 2006, 163) i u ostalim društvenim uređenjima. Ponekad se radi o rasnim razlikama, kao primjerice u Sjedinjenim Američkim Državama, koje su u određenoj mjeri kodificirane i u privilegiranim elektorskim glasovima, koji se često pokazuju determinirajući za opću političku sliku. Inače kategorija ostalih, iako, po našem istraživanju nepostojeća u bilo kojem drugom ustavnom okviru, bi se mogla usporediti s distinkcijom između građana i ne-građana. Ostalima pripada kategorija negrađana, koji iako punopravni građana Bosne i Hercegovine, nemaju potpuno mogućnost sudjelovanja u političkom životu, na koji imaju isključivo pravo, gotovo monopol, članovi pojedine od etnija.

Specificum koji proizlazi iz Daytonskog ustava je to da pojedinci koji imaju puna građanska prava bivaju, zbog nepripadnosti trima dominantnima 
etničkim kategorijama, limitiranog političkog života. Daytonski specifikum je u stupnju eksplikativnosti kojom se diskriminacija ističe. Iako su slične prakse postojala već u začetku i na prvim višestranačkim izborima u Bosni i Hercegovini iste su sada ustavno kodificirane i kao takve eliminatorni element za bilo kakve eurointegracije.

Mišljena smo kako aktualni izborni zakon posjeduje inherentne limite koje su vezane za ljudska prava. Individualna ljudska prava i one kolektivna nisu na zadovoljavajući način artikulirana u istom. No, problematika ljudskih prava reflektira nejasnoće prisutne u Deklaracija o pravima čovjeka i građanina iz 1789. (uzimamo je kao vjerojatno utemeljujući trenutak modernih demokracija). Talijanski filozof Giorgio Agamben, dobro uočava problematiku odnosa čovjeka, individualne kategorije, i građanina. Kome su namijenjena ljudska prava? Konkretnom čovjeku, individui ili pak njegovom građanskom okviru, pravnom statusu i državnom okviru? Jacques Maritain, inače jedan od suautora Opće deklaracije o pravima čovjeka slično tvrdi, uvodeći razliku između posjedovanja ljudskih prava i ostvarivanja istih (Usp. Maritain, 1992, 105-106). I Habermas je na sličnom tragu na mnogo mjesta, posebice u djelu Između činjenica i normi, kada ukazuje na diskrepanciju normativnog okvira i provođenja istog.

U slučaju aktualnog izbornog zakona dogodila se i dodatna redukcija. Ne samo da se radi o neprovođenju određene pravne norme, već se radi o konstitucionalnoj isključenosti određene kategorije iz određenih sfera političkog života. „Ostali“, po definiciji ne pripadaju niti jednoj od tri dominantne etnonacionalne političke paradigme.

\section{Konsocijacija izmedu ideje i stvarnosti}

Državni okvir Bosne i Hercegovine odražava etno-nacionalnu ideju, doduše u složenijem obliku, onom konsocijacije. Konsocijacija, kao elaborirani koncept, se po prvi put javlja u djelu relativno nepoznatog Johanessa Althiusa (1557-1638), njemačkog filozofa koji u svom djelu Politica Methodice Digesta et Exemplis Sacris et Profanis Illustrata, uvodi ideju konsocijacije, koja je kasnije poslužila kao temeljna ideja svakog budućeg uređenja federativnog tipa. U kontekstu 16. i 17. stoljeća, protestantske reformacije i vjerskih ratova koji će kasnije uslijediti, potrebno je bilo fundirati novi državnu arhitekturu. Althusius upravo to i čini, te smatra da su ljudi povezani u određene temeljne zajednice, poput obitelji, grada, provincije i sl. Radi se, očito je, o predpolitičkim stvarnostima. Moć države kreće od upravo ovih najnižih 
konsocijacijskh schema. Iako su konsocijacijski entiteti koji će se razviti subordinirani državi, ipak su kolektivno superiorniji. Reći će Althusius, kako „međusobna komunikacije ili suradnja, involvira stvari, usluge i javna dobra” (Althusius, 1603, 7)

Koncizno predstavljena, za Althisiusa, politika je deskriptivna znanost o činjenicama. Nešto ekstenzivniji okvir: „Politika je umijeće povezivanje (consociandi) ljudi s ciljem ostvarivanje, njegovanja i čuvanja društvenog života između njih. Dakle, naziva se "simbiotika“" (Althusius, 1603, 7). Subjekt politika je udruživanje (consociatio), u kojemu ih simbioza obvezuje jedne prema drugima, eksplicitnim ili prešutnim dogovorom, za recipročnu komunikaciju bilo čega korisnog ili nužnog za harmonično odvijanje društvenog života. (Althusius, 1603, 12).

Althius je u odnosu na druge novovjekovne političke autore, poput recimo Bodina i Macchiavellija, ostao bez toliko pozornosti. No, revival njegove ideje konsocijacije javlja da krajem 60-ih godina prošlog stoljeće preko Arenda Lijpharta. Isti će u svom radu Konsocijalna demokracija (Usp. Lijphart, 1968, 207) reafirmirati ideje Althiusa. Osim direktne referencije (fusnota 14) na Althiusa, Lijphard će njegove ideje primijeniti na fragmentirane ali stabilne demokracije, donoseći i nekoliko povijesnih primjera (Švicarska, Beligja, Austrija).

Realnost konsocijacije. Konsocijacijska tipiziranost bh društva je tolika da gotovo u potpunosti odgovara Lijphartovom modelu, koji je iz 60-ih godina prošlog stoljeća. Arendt Lijphart, tvrdi da za promicanje pregovaranja i kompromisa konsocijacijski sustavi moraju sadržavati četiri ingredijenta. Povezivanje fragmentiranog društva vrši se kroz institucionalni dizajn "velike koalicije" koja je upotpunjena s tri pomoćna instrumenta. "Obostrani veto" je mehanizam koji onemogućuje preglasavanje posebice kada je u pitanju vitalni interes. Ovaj mehanizam jamči, po Lijphartu, potpunu političku zaštitu (Usp. Lijphart, 1977, 36-37). Ali, realističan je Lijphard, kada ističe kako veto može dovesti do tiranije manjine (Usp. Lijphart, 1977, 37). Proporcionalnost Lijphart suprotstavlja principu "pobjednik uzima sve" a uz to, proporcionalni izborni sustav, koji omogućava političko predstavljanja svake značajnije skupini u društvu, ključan je za rad modela (Usp. Lijphart, 1977, 41). Segmentarna autonomija, četvrta je sastavnica konsocijacijskog modela (Usp. Lijphart, 1977, 41-44).

Ograničenja konsocijacijskog modela, svaki građanin Bosne i Hercegovine empirijski doživljava gotovo svakodnevno. Naime, disfunkcionalnost koja je konstitucionalno legitimirana transponira se u gotovo svaku od sfera javnog 
života. Velike koalicije su vrlo fragilnog karaktera, obostrani veto se koristi na granici s trivijalnošću, ne postoje egzaktni podaci o proporcionalnosti na čitavom teritoriju Bosne i Hercegovine, a segmentarna autonomija slijedi često logiku moći.

Iako u stvarnosti poprilično nefunkcionalnog karaktera, makar u slučaju Bosne i Hercegovine, čini se, kako je konsocijacijski model najbolji za duboko pluralna društva. Četiri sastavnice pluralnog društva prema Lijphartu, za koje je konsocijacijski okvir izvorno i zamišljen, čini se da odgovaraju pluralnom bosanskohercegovačkom društvu:

1. U potpuno pluralnom društvu, mora biti moguće egzaktno identificirati segmente na koje je društvo podijeljeno;

2. Mora biti i moguće egzaktno iskazati veličinu svakog segment, tj., koliko ljudi pripada svakom od segmenata.

3. U potpuno pluralnom društva, mora postojati savršene korespondencije između segmentarnih granica i granica između političke, društvene i ekonomske organizacije;

4. Političke stranke pokrivene su trećim kriterijem. Završni test potpuno pluralnog društva je taj, da budući da stranke i segmentirane lojalnosti koincidiraju, trebala bi postojati mala ili nikakva promjena u podršci različitim strankama od izbora do izbora: u savršeno pluralnom društvu, izbori su naprosto cenzus segmenta (eng. segmental census) (Usp. Lijphart, 1981, 355-359).

\section{Kritički pogled na etno-partitokracija}

\section{Inherentni limiti etno-partitokracije}

Metaideja koje prožima Lijphardove ideje o konsocijaciji je povezivanje suprotnosti, uz veliku ulogu lidera suprotstavljenih društvenih aktera. Reći će, $\mathrm{u}$,konsocijacijskim demokracijama, politika se tretira ne kao igra nego kao biznis" (Lijphart, 1968, 216). Zanimljivo je povezati tvrdnju Maxa Webera, koji dotičući se švicarskog proporcionalnog sistema kojega su i neke njemačke regije željele primijeniti, ističe kako se s tim modelom, federativnim, željelo „državu i njene položaje tretirati kao čistu instituciju za osiguranje sinekura“ (Weber, 1999, 171) Ne može biti drugačije niti u slučaju Bosne i Hercegovine, poprilično je očita konstatacija.

Nije nužno ni dijeliti sve stavove Maura Calisea, iako se teško oteti dojmu da je bio potpuno u pravu kada je istakao kako je ,problem demokratizacije 
države” ništa drugo nego „konstitutivni problem partitokracije”. Precizira Calise kako su „masovne stranke, koje su dugo vremena bile izvan državnih okvira, sada napokon imaju pristup njima u ime masa čiji će glas organizirati i prevesti u političko pravo" (Usp. Calise, 1994, 5). Ne čine se pretjeranima niti tvrdnje, E. E. Schattschneidera koji u knjizi Party Government ističe kako su upravo političke stranke stvorile demokraciju, naravno u modernom smislu, te ih stoga treba promatrati kao centralni i determinirajući element u razvoju iste (Usp. Schattschneider, 1960, 1-10). Politička stranka nije drugo, jasan je Schattschneider, nego organizirani pokušaj dolaska do moći (Usp. Schattschneider, 1960, 35). Spomenuto Schattschneiderovo djelo je 60-ih godina prošlog stoljeća predstavljalo embrionalni doprinos razvoja analize i važnosti političkih stanaka. Sa značajnim vremenskim odmakom, iz današnje perspektive, unatoč eroziji svekolike stranačke infrastrukture, ipak je lagano konstatirati važnost institucionalnih organizacija, poput stranaka, za svekoliki politički život. Stranke su, poprilično determinirajuće, za sveukupni politički život.

Kombinacija „etničke kutije“, stranačkog monopola, generalno turbulentnog stanja pred disoluciju bivše Jugoslavije, postaje realnost u slučaju Bosne i Hercegovine. Neovisno i partnerskim porukama između lidera i struktura stranaka s nacionalnim predznakom, ipak je vrlo brzo etnička paradigma dovela do duboko polarizirajućih pozicija, I to ne vezanih za društveno-političke marginalije već za temeljne društvena shvaćanja. Temeljna divergencija i reducirana mogućnost smislenog koaliranja dovodi, vrlo očekivano, do hostilnosti (Usp. Reilly, 2001, 7-10), a navedena je čest pratitelj „,demokracije u podijeljenim društvima“", kako ju Reilly naziva.

Rat je u ovom slučaju bio gotovo očekivani nastavak politike drugim sredstvima. Donald Horowitz, renomirani ekspert za etničke konflikte, ističe kako „nigdje recipročna veza između stranke i društva nije jasnija nego u etničkim politikama", budući da se apeliranjem na elektorat u isključivom etničkom ključu generira i sam etnički konflikt generira (Usp. Horowitz, 1985, 291). Samorazumljivo je ono što Horowitz ističe, kako etničke stranke zastupaju interese te etničke grupe, ali isti interesi kroz ekskluzivni karakter navedenih stranaka postaju prvi indikator podijeljene politike (Usp. Horowitz, 1985, 292). Zacementiranost etničkih stranaka najpovoljnija je za same lidere i članove, poznato nam je to.

Svjestan neuspjeha konsocijacija, Lijphart će istaći kako je za uspjeh kosocijacijskog modela trebati: 1 . Sposobnost elita da prilagode divergentne interese i zahtjeve subkultura; 2. Sposobnost nadilaženja podjela i razvijanje zajedničkih napora s rivalnom subkulturom; 3 . Njihov trud za održavanje 
sistema i razvoj kohezije i stabilnosti. Sve ovo uz pretpostavku da lideri shvaćaju problematiku političke fragmentacije. (Lijphart, 1968, 216). Dobar dio stranačkih politika u Bosni i Hercegovine intencionalno minira sve sastojke nužne za funkcionalnost konsocijacijskog modela.

Inherentni problem etnički utemeljenih politika se većinom svodi na temeljne probleme svake političke teorije i prakse: teritorijalni problem i želja za efektivnom kontrolom istog, što predstavlja neki oblik suverenosti, suženog doduše tipa, ali u kontekstu želje za autodeterminacijom vrlo razumljiv. Iako kako smo već naveli, teritorij Bosne i Hercegovine je etnički klasificiran, zahvaljujući popisima stanovništva te je navedeno poslužilo kao okvir raznih budućih političkih aspiracija. Bosna i Hercegovina, unatoč tome što je konceptualno određena kroz prizmu statističke nacionalizacije, ipak je toliko divergentan teritorij koji naprosto ne može nego biti teritorijalno podijeljen čak niti na neki duboko nehumani način. Konceptualna politika koja je primijenjena na teritorij Bosne i Hercegovine, a temeljila se na klasičnim sastavnicima svake etno-nacionalne politike pokazalo se nakompatibilnom za sam teritorij Bosne i Hercegovine. Naime, svaki od, kasnije konstitucionaliziranih konstituenata, nazvati ćemo ih apstraktno, x, y i z, unutar određenog teritorija predstavlja većinsku ili manjinsku populaciju. Prevedeno, znači da je svaki građanin Bosne i Hercegovine $\mathrm{x}$, na određenom dijelu teritorija tretiran kao „Ostali“, pa i kada je dio jednog od konstitutivnih naroda. Gotovo bezbroj institucionalziranih stereotipa prema samoj stvarnosti Bosne i Hercegovini, primjerice onaj o ,vjekovnoj mržnji“ konstituenata, koje je beskrajno brutalni rat dodatno potencirao utjecale su i na nastanak novog ustavnog okvira.

Ako etnopolitike, unatoč dogovorenom partnerskom odnosu, koji je često prerastao u funkcionalni ortakluk, nisu u stanju zaštiti populaciju koja odudara od relativno većinske na prostoru jednog određenog, često, iz šire perspektive, poprilično beznačajnog, teritorija, to ukazuje na inherentni limit navedene politike. Monstruoznosti koje su karakterizirale 90. godine prošlog stoljeća u svim svojom nijansama i fenomenologijama, idejni su nasljednik etnopolitika.

\section{Obrisi kritičke teorije i „Ostali“}

Max Horkheimer, jedan od pilastra Frankfurtške škole, u uvodu u svoju Kritičku teoriju, dobro reprezentira zeitgeist dekade, vežući vlastite motivacije za razvoj kritičke teorije s jednostavnom željom posebice mladeži za „boljim životom i pravim tipom društva“ te „odbijanjem prilagodbe tadašnjem 
redu stvari“ (Horkheimer, 1972, viii). Njemački autor ističe nužnost sagledavanja problema iz više različitih aspekata, izbjegavajući jedan dominantan aspekt, ili jednu dominirajuću perspektivu. Jedna od temeljnih ideja kritičke teorije briga je za „razumne uvjete života“, zatim osuda postojeće društvene institucije i prakse kao nehumane i teorija koja promišlja potrebu za alteracijom društva u cjelini (Horkheimer, 1972, 189-199).

Izborni zakon Bosne i Hercegovine zasigurno potrebuje alteraciju. Ustavna diskriminatorna praksa zaslužuje osudu. Posebice iz perspektive ljudskih prava i generalno demokratskog standarda, njegov diskriminatorni karakter posebice u pogledu problematike „ostalih“, teritorijalne asimetrije i ostalog, onemogućuje prihvaćanje razvijenih demokratskih standarda.

S druge strane, i etnonacionalna paradigma je nepotpuno i iz perspektive same paradigme. Primjerice, nemogućnost teritorijalizacije vlastitog biračkog tijela, unutar Federacije Bosne i Hercegovine, izaziva reakciju velike većine stranaka okupljenih oko hrvatskog nacionalnog predznaka. Politička artikulacija navedenog, koja je sasvim razumljiva unutar navedenog okvira, se većinom svodi na strah od fenomena preglasavanja i na izbor tzv. nelegitimnih predstavnika.

Političko predstavljanje. Hanna F. Pitkin se pita o ideji političkog predstavljanje, te lagano možemo njezinu ideju transponirati u domenu etničkih stranaka. Pitkin se pita da li je kod političkog predstavljanja riječ „,samo o fikciji, o mitu koji je dio našeg društvenog folklora. Ili, da li se predstavljanje redefinira kako bi odgovaralo politici?" (Pitkin, 1967, 221). Ako, na temelju prethodnog teoretskog okvira, navedene ideje primijenimo u kontekstu bosanskohercegovačke političke paradigme i šireg stranačkog života, kao da ispada da su stranački lideri neprikosnoveni monopolisti pojedinačne volje vlastitih etnija. Tako kolektivizirana volja u jednom individualnom principu, onog lidera stranaka s nacionalnim predznakom, demokratski je deficitarna čije se prakseološke implikacije zrcale u trenutku potrebe za nešto složenijim političkim dogovorom. Navedeno dovodi do generalne percepcije, fundirane u gotovo bezbroj egzaktnih i mjerljivih podataka, stagnacija bosanskohercgovačkog društveno-političkog života. Komparativni pristup pokazuje kako se u bosanskohercegovačkom slučaju politizacija etničkog sukoba - iz šire perspektive izbornog zakona - odvija na nivou banalnih društevno-povijesnih konstatacije koje su oportunistički instrumentalizirane. Ovakav koncept umanjuje mogućnost aktivnog sudjelovanja građana u izbornom sustavu, potiče etnoekskluzivnost te dekuražira svaki oblik meritokracije i otežava tzv. crossethnic voting. 
Ako stranke s etnonacionalnim predznakom svedemo na zajednički nazivnik, onda bi se njihovo djelovanje svelo većinom na želju za što većim potenciranjem glasača kao jednostavnih „etničkih kutija“ koji da, posjeduju slobodu izbora, koja je realno gotovo nepostojeća, budući da njihov glas gotovo po defaultu ide pripadajućim im etničkim strankama. Ne radi se baš, očito je, o nekom obliku izborne slobode. Naprotiv, radi se o limitiranom participiranju pojedinaca u javnom životu, koji, umjesto umjesto da glasaju za bilo kakav oblik izbornog programa, odabire glasati po automatizmu. Elektorat je u Bosni i Hercegovini shvaćen na principu „etničkih kutija“, na čiju smo genezu već ukazali, te gotovo da se pretpostavlja da pojedinac shvaćen kolektivno kao dio jedne ,etničke kutije“ ne može nego glasati za istu. Etnonacionalna paradigma, unaprijed dana, se time suprotstavlja individualnom izboru pojedinca, budući da naglasak stavlja na kolektivni imaginarij, kojega elektorat u biti niti ne izabire, već izbornim činom samo konstatira isti, dajući mu formalni legitimitet. Može nam biti korisna sociologa Niklasa Luhmannova po kojoj se društvo ne sastoji samo od ljudi (pojedinaca, individua) već od komuniciranja, i to kako ga on, poprilično tehnički naziva, strukturalnog uparivanja (eng. coupling) između različitih sistema (etničkih, individualnih, klasnih) (Usp. Luhman, 1979). Izbori generalno, moraju pojedincima dati mogućnost za ostvarivanje navedenog, ili makar za izborni pokušaj ostvarivanja istog.

\section{Zaključna razmatranja ili o modelu ,inkluzije osjetljivom na razlike“6}

Europska praksa. Iako uvažavamo svaki politički stav, ipak smo mišljenja da se inherentni limiti izbornog zakona koji su artikulirani na dvije razine, onoj međunarodnoj i domaćoj, trebaju rješavati na način da se preuzme neki od postojećih nediskriminatornih europskih modela u materiji izbora. Generalni kontekst bosanskohercegovačke politike, s već notornom disfunkcionalnošću sistema, teško može sam ponuditi rješenja. Čak i da je u stanju, osnovano je sumnjati da li bi navedeni prijedlog udovoljavao minimumu europskih standarda.

Politički okvir. Poznata je velika diskrepancije između „,normi i konkretnog ponašanja“, Habermasovim rječnikom, između ljudskih prava koja se ostvaruju samo unutar određene političke zajednice. Ne ulazeći detaljnije u samu Habermasovu analizu, tenzija koja postoji između univerzalnih ljudskih prava i onih građanskih, a navedeno je primjenjivo na slučaj „Sejdić-Finci“, 
može, makar u teoriji, ojačati i sam institucionalni okvir Bosne i Hercegovine. Naime, borba za inkluzivnije društvo u kojemu sugrađanin, što je i bosanskohercegovački paradoks, ne može biti niti kandidat za već mnogo puta spomenute pozicije, dobar je početak nekih pozitivnih društvenih procesa. Iako, opća desenzibilizacija ljudi bilo realnom politikom, što se očituje kroz veliki stupanj apsentizma na izborima i općenito u javnoj sferi, ipak svjedoči kako promjene teško dolaze odozdo. Konstitutivni defekt Bosne i Hercegovine, vezan u prvom redu za koncepciju ostalih, primjer je nedovršenosti konstitucionalne arhitekture te ga interpretiramo ekstenzivnije. Naime, unutar suverenog teritorija Bosne i Hercegovine, neovisno o administrativnoj podjeli, velika je vjerojatnost da osoba x bude izložene većem ili manjem stupnju diskriminatornog ponašanja, ovisno o tome da li je dio manjinske ili većinske populacije. Problem ostalih je individualan problem gotovo svakog od nas, nužno je naglasiti ovu dimenziju individualne i socijalne empatije. Nepotpunost etnonacionalnog političkog okvira možda je moguće komplementirati uvodeći najbolje europske prakse u zaštiti individualnih i kolektivnih ljudskih prava. No, ti komplementirajući elementi kose se s osnovnim postavkama etnonacionalizma, koji je ipak, u manjem ili većem stupnju, ipak ekskluzivne prirode i dominantan.

Individualna i kolektivna prava. Ne postoji niti približan teoretski konsenzus o shvaćanju odnosa kolektivnih i individualnih prava. Iz perspektive zapadnih razvijenijih demokracija, ostvarivanje kolektivnih prava se većinom odvija iz perspektive individualnih prava, koja su poprilično široko određena te posjeduju kapacitet prihvaćanja i kolektivnih prava. U Bosni i Hercegovini postoji tendencija dominacije kolektivnog imaginarija, neovisno o kojoj se varijanti radi. Izborni zakon mora omogućiti razvijanje inkluzivnijih crta društva te lišen diskriminatornih elemenata. Dodat ćemo, na Habermasovom tragu, model inkluzivnijeg društva, osjetljiv na različitosti, individualnog i kolektivnog tipa. Habermas koji razvijajući model osjetljiv na različitosti, ističe kako su realnosti poput federalne podjele nadležnosti, zatim nužne decentralizacije, zajamčene kulturne autonomije i prava koja se tiču određenih grupa nužni u jednom multikulturnom društvu. Iako Habermas direktno analizira fenomen multikulturalizma, smatramo kako je navedeni okvir u određenom mjeri primjenjiv i na slučaj Bosne i Hercegovine. No, također upozorava kako unatoč različitostima, nužno je stvoriti ,povezujuću snagu zajedničke političke kulture", koja implicira da svi dionici političkog života posjeduju zajednički politički jezik i s time, mogućnost artikuliranja kako kolektivnih tako i individualnih interesa (Usp. Habermas, 2018, 146). Habermas često definira demokraciju kao poredak koji trajno, u institucionalnom smislu, osigurava 
medij za artikuliranje individualnih perspektiva te posjeduje mehanizme za njihovo racionalno usaglašavanje. Nasuprot ovome, bosanskohercegovački demokratski okvir privilegira kolektive čiji predstavnici minimalno uspijevaju artikulirati individualne perspektive a kamoli da bi ponudili mehanizme za rješavanje istih.

Bosna i Hercegovini tek slijedi ta evolucija od etničkih politika prema građanskih, koje su se pokazale i kao najuspješnije u zaštiti svih ljudskih prava, od individualnih do kolektivnih. Zapadne razvijene demokracije svjedoče o tome, unatoč mnoštvu kompleksnih izazova s kojima se susreću. Trenutno, političke strukture Bosne i Hercegovine nisu u stanju ostvariti taj evolucijski skok s etničke na građansku paradigmu, uz sasvim razumljivu zaštitu određenog seta prava koja se tiču određenih grupa. Time postaje očit demokratski deficit prisutan u bosanskohercegovačkom društvu. Darwinovim rječnikom, „missing link“ između dvije paradigme, one etničke koja ima evoluirati u građansku, ne u amorfnom obliku, već u autentičnom pluralnom, tek treba nastupiti. Nova paradigma bi se lako transponirala i u izborni zakon.

\section{Bibliografija (red citiranja u tekstu)}

Holbrooke, Richard. To End a War: The Conflict in Yugoslavia--America's Inside Story--Negotiating with Milosevic. Modern Library, 2011.

Weller, Marc. "The post-Yugoslav experience." Weller, Marc, and Stefan Wolff, eds. Autonomy, self-governance and conflict resolution: Innovative approaches to institutional design in divided societies. Vol. 33. Psychology Press, 2005, 43-49

Sartori, Giovanni. Parties and party systems: A framework for analysis. ECPR press, 2005

Rabushka, Alvin, and Kenneth Shepsle. "Politics in plural societies." Columbus, OH: Charles E. Merrill 232 (1972). 186-199.

Malešević, Krstan. "Marginalije o Be Ha izborima'90.” Revija za sociologiju 22.3-4 (1991)

Brubaker, Rogers. Ethnicity without groups. Harvard University Press, 2004, 54.

Stourzh, Gerald. From Vienna to Chicago and back: essays on intellectual history and political thought in Europe and America. University of Chicago Press, 2010. 154

Stegar, Rok - Scheer, Tamara. "Ethnic boxes: the unintended consequences of Habsburg bureaucratic classification." Nationalities papers46, no. 4 (2018): 575-591.)

Rehfeld, Andrew. The concept of constituency: Political representation, democratic legitimacy, and institutional design. Cambridge University Press, 2005. 34

Holden, Matthew. "Exclusion, inclusion and political institutions." The oxford handbook of political institutions 2 (2006): 163.

Lijphart, Arend. "Consociational democracy." World Pol. 21 (1968): 207

Lijphart, Arend. Democracy in plural societies: A comparative exploration. Yale University Press, 1977. 36-37.

Lijphart, Arend, Consociational theory: problems and prospects. Comp. Polit. 1981, 13:355-59

Reilly, Benjamin. Democracy in divided societies: Electoral engineering for conflict management. Cambridge University Press, 2001.) 
Schattschneider, Elmer Eric. Party government... Transaction Publishers, 1960.1-10

Calise, Mauro. Dopo la partitocrazia: l'Italia tra modelli e realtà. Vol. 26. Einaudi, 1994. 5

Horowitz, Donald L. Ethnic groups in conflict, Univ of California Press, 1985.) 291

Horkheimer, Max. Critical theory: Selected essays. Vol. 1. A\&C Black, 1972., viii.

Bieber, Florian. "Undermining democratic transition: the case of the 1990 founding elections in Bosnia and Herzegovina." (2014): 548-555.

Belloni, Roberto. "Peacebuilding and consociational electoral engineering in Bosnia and Herzegovina." International peacekeeping 11.2 (2004): 334-353.

Maritain, J. (1992). Covjek i drzava. Nakladni zavod Globus-Skolska knjiga, Zagreb.

Althius, Johannes, Politica Methodice Digesta et Exemplis Sacris et Profanis Illustrata (Politics methodically arranged and illustrated by holy and profane examples [Herborn, 1603; 2nd enlarged ed., Groningen, 1610; 3rd enlarged ed., Herborn, 1614]).

Pitkin, Hanna F. The concept of representation. Vol. 75. Univ of California Press, 1967.

Habermas, Jürgen. Inclusion of the other: Studies in political theory. John Wiley \& Sons, 2018.

\title{
Election Law of Bosnia and Herzegovina and the Limits of Ethnonational Paradigm
}

\begin{abstract}
The Election Law of Bosnia and Herzegovina is, in its specific legal form, a faithful reflection of the general principles defined by the Dayton Constitution that calcified the ethnic division of the country. The interdisciplinary approach to the constitutional determinants present in the election law also shows clear features of the political consciousness that brought it about. The first part of the article tries to reconstruct the dominant political and social idea behind the election law. The Election Law of Bosnia and Herzegovina is an example of unfinished constitutional and state architecture, especially in the form of unfinished ethno-national fixism and related human rights issues. The ethno-national paradigm, evident since the first multi-party elections in Bosnia and Herzegovina, emphasized ethnic grouping more than the electoral process itself. The concept of "statistical nationalization" will be analyzed as well. The second part of the article confronts the dominant idea of the election law of Bosnia and Herzegovina with certain aspects of political theory. The constitutional category of constituents is privileged over the category of "Others", which is a brutal example of discriminatory practice, which, as expected, is not in line with any normative document related to human rights. Even from an ethno-national perspective, the said Election Law is incomplete. Furthermore, the inherent limits of the consociational framework were analyzed.

The third part of the article analyzes the limitations of ethno-partitocracy, showing that in one such system, the individual perspective is almost non-existent. The outlines of critical theory indicate the necessity of the alteration of certain social realities and the creation of a social model sensitive to diversity but directed towards the developed democratic achievements.
\end{abstract}

Keywords: BiH election law - ethnonational paradigm - statistical nationalization - constituents - inclusion 